\title{
Philippine Poverty as Moving Fractals
}

\author{
Roselle Jardin Ranario \\ Department of Public Governance, College of Arts \& Sciences \\ Cebu Normal University \\ Email: bkind2roselle@yahoo.com
}

Received: March 30, 2016 Accepted: April 15, 2016 Published: May 13, 2016

doi:10.5296/jpag.v6i2.9369 URL: http://dx.doi.org/10.5296/jpag.v6i2.9369

\begin{abstract}
A recent innovation in the field of statistics is using fractal analysis where data sets are analyzed for anomaly detection, pattern analysis, and root cause analysis. In application of the fractal statistics, this paper examines the incidence of Philippine poverty from 2003 to 2012 based on its fractal dimension in the hope of providing policy makers a different approach in addressing sustained growth among the poor. Poverty is like a moving fractal where patterns simply repeat in various scales and variations. What are the key implications of fractal poverty for policy and research? How can the fractal poverty provide an analytical foundation to make a pathway out of poverty accessible to Filipinos presently suffering in extreme poverty? The fractal model shows that poverty incidence is dictated by provinces whose poverty incidence are high. This means that if the poverty incidence of the province will be primarily addressed, it will affect the poverty scenario of the Philippines. Policy makers if looking for key indicators why Filipinos have some difficulty escaping poverty may focus on the province with the highest incidence.
\end{abstract}

Keywords: Philippine Poverty, Fractal Model, Monofractal 


\section{Introduction}

More than 8 million people around the world die each year because they are too poor to stay alive (Sachs, 2006). World Bank (1997, as cited by Morduch, 1999) described that in the world today, about 1 billion people live on less than $\$ 1$ per day, and about 2-3 billion live on less than $\$ 2$ per day. This scenario triggered a growing concentration of world poverty particularly in slow-growth areas of South Asia and Africa. A generation ago, approaches to poverty alleviation were also considerably different. While there had been an active macroeconomic agenda on "redistribution with growth," much of its approaches through the 1970's and mid-1980's tended to focus on poverty alleviation as a static problem (Murdoch, 1999).

It has been noted that economic growth would play an important role in poverty alleviation. Unfortunately, such advancement appeared dim in poor countries. Sachs (2006) identified 8 reasons why countries fail to achieve economic growth: that poverty itself is the cause of economic stagnation, physical geography, fiscal trap, governance failures, cultural barriers, geopolitics, lack of innovation and demographic trap. The key problem for the poorest countries is that poverty itself can be a trap. When poverty is very extreme, the poor do not have the ability by themselves to get out of the mess. Our generation's challenge is to help the poorest of the poor to escape the misery of extreme poverty so that they may begin their own ascent up the ladder of economic development.

In the Philippines, a wide range of social protection programs is in place. However, in the latest report of the National Statistics Coordination Board (NSCB-PR, April 23, 2013) poverty incidence remain unchanged as of [first semester] 2012. The subsistence incidence between 2006, 2009 and 2012 remain insignificant. Inadequate human capabilities and limited access to social services are often key factors underlying poverty and inequality in the country.

However, a different model in understanding poverty incidence of the Philippines may generate a different strategy in reducing the perennial problem in the country. This paper examines the incidence of Philippine poverty from 2003 to 2012 based on its fractal dimension in the hope of providing policy makers a different strategy in addressing the sustained growth among the poor. Poverty is like a moving fractal, where the status keeps on changing, but the basic pattern simply repeats itself in various scales and variations.

What are the key implications of fractal poverty for policy and research? How can the fractal poverty provide an analytical foundation to make a pathway out of poverty accessible to Filipinos presently suffering in extreme poverty? Our generation's challenge is to help the poorest of the poor to escape the misery of extreme poverty so that they may begin their own ascent up the ladder of economic development.

\section{Conceptual Framework}

Poverty status behaves like a fractal: very uneven at large scales and at small scale. The time series plot of Philippine poverty incidence (figures 1-4) shows that the fractals have the same amount of "jaggedness" or "unevenness" at every scale. It's as if there is an almost 


\section{Ml Macrothink}

identical pattern in the "roughness" of the plot between years. Status of poverty in the Philippines though perceived to be constantly changing shows a similar pattern for each year.

Different analysts from different disciplinary traditions, find different correlates of persistent poverty and posit different causal mechanisms. Barrett and Swallow (2006) noted that the causality behind the poverty trap phenomenon nonetheless remains murky. Fractal statistics will provide a reliable base for understanding poverty status. Using minitab, the fractal dimension was determined based on the poverty incidence for the year 2003, 2006, 2009 and 2012. It is interesting to note that basic statistics based on the Family Income and Expenditure Survey (FIES, 2012) survey suggests that poverty incidence remains unchanged since 2003 to the first semester of 2012. And that slight changes are insignificant. This means that economic growth for the past for the past 6 years hardly made a dent in poverty incidence, as percentage of Filipinos living below the poverty line remained practically the same between 2006-2012 (Olchondra, Philippine Daily Inquirer, 2013).

Analyzing the fractal dimension of poverty incidence will provide a pathway in understanding how and why poverty incidence remains to be "practically unchanged" since 2009 despite the country's expansion of the economy. Where is the "trickle down effect"? Is it possible to have a fractal pattern of poverty that made the country difficult to escape?

Figure 1. Fractal Plot of 2003 Poverty Incidence Figure 2. Fractal Plot of 2006 Poverty
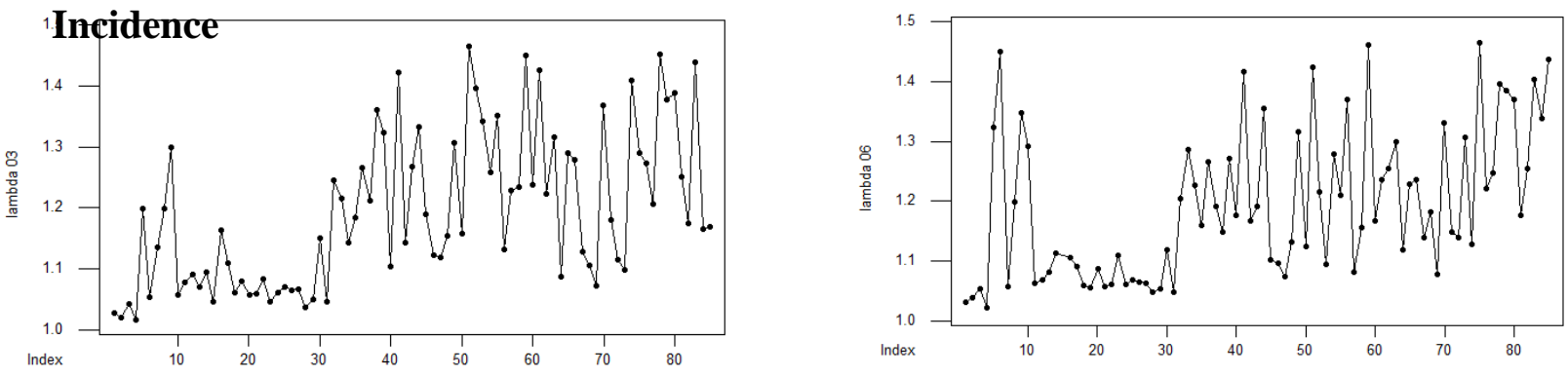

Figure 3. Fractal Plot of 2009 Poverty Incidence Figure 4. Fractal Plot of 2012 Poverty
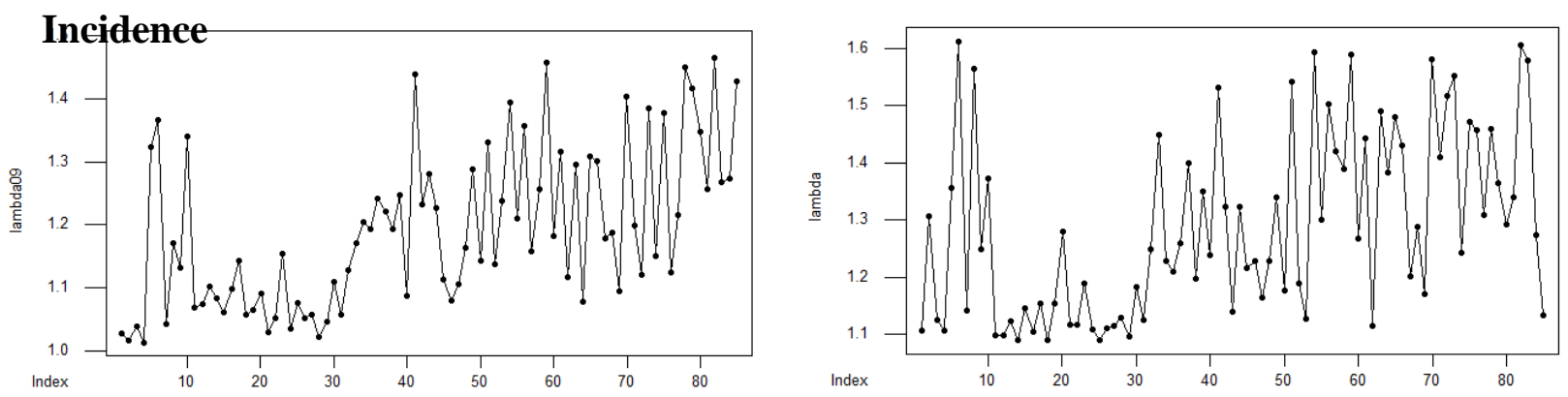


\section{Fractal Model and Analysis of Philippine Poverty}

The time series plot shows an almost identical scale of poverty incidence in the Philippines for the year 2003, 2006, 2009. This implies that poverty reduction strategies for these years may not provide any significant changes to alleviate poverty. Although all graphs showed a monofractal dimension, the status in 2012 provided a different scale, more of a straight line instead of a curve. This would imply that the status of poverty of the Philippines is dictated by provinces whose incidence is high.

Fractal analysis revealed that poverty alleviation programs implemented in the years 2003 -2009 remains unchanged. Meaning there was not much effect on the graphical representation of the data, as such we can then surmise that Poverty Alleviation efforts were weak and needed radical change to become effective. The difference of the fractal dimension between 2003-2009 and 2012 is due to the government interventions implemented in the year 2010. A different government intervention was introduced known as Pantawid Pamilya. Through the leadership of the Department of Social Welfare and Development (DSWD) implemented the Conditional Cash Transfer (CCT) Program dubbed as Pantawid Pamilyang Pilipino Program provided income support to extremely poor households that would encourage them to increase investments in their children's human capital, 4Ps will serve as the lead vehicle through which the many cross-cutting issues (e.g. targeting, monitoring and evaluation) will be addressed (4Ps Concept Paper, 2009).

The focus is on building human capital in the poorest families (through investments in their health/nutrition and education) as low schooling and poor health are strongly linked with the poverty cycle in the Philippines. It provides social assistance through health and education conditional cash grants which are transferred upon the compliance of beneficiaries with the program conditions. Aside from this, 4Ps also helps fulfill the country's commitment to meet the Millennium Development Goals, namely: (a) Eradicate Extreme Poverty and Hunger, (b) Achieve Universal Primary Education, (c) Reduce Child Mortality, (d) Improve Maternal Health, and (e) Promote Gender Equality.

The fractal spectrum revealed that in the year 2003, 2006 and 2009 are similar in its poverty distribution. But looking at the histogram of 2012, the distribution of poverty has been corrected such that the figure shows a concentration of the points in one straight line. The latter year is unique due to government intervention in redistributing the wealth of nations through the programs on poverty alleviation. It can be deduced that the 4Ps which the program of the government giving aid to those who are below the poverty line are indeed effective. Since the implementation of the project, poverty in the lowest level has been resolved, although the intensity of its effect is only felt in recent years.

According to Barrett and Swallow (2006), there are fractal poverty traps that lead to chronic poverty at multiple scales of socio-spatial aggregation. Poverty traps result from nonlinear processes at individual, household, community, national and international scales that cause the coexistence of high and low equilibrium levels of productivity and income and high and low rates of economic growth. This leads to the fact that the key implications of fractal poverty traps include (i) the importance of recognizing meso-level phenomena in addition to 
conventional micro- and macro-level issues, (ii) inter-connections across social-spatial scales that foster or ameliorate chronic poverty, (iii) the importance of identifying and overcoming thresholds at which accumulation and productivity dynamics bifurcate, and (iv) the significant potential role of transitory donor and government interventions and safety nets to ignite sustainable growth among the poor (Barrett and Swallow, 2006).

The histogram presents that the bulk of distribution of poverty incidence is on small scale than in large scale which means that there are more people on extreme poverty level. This is because Philippine population remains to be high. NSCB (as cited by PDI, April 2013) reported the poverty incidence was practically unchanged in the past six years, the number of poor people was expected to be higher in 2012 because of the country's growing population. Norio Usui (as cited by PDI, April 2013) senior country economist for the Asian Development Bank, said the government must solve the problem of jobless growth if it hoped to reduce poverty. "The benefits of strong economic growth have not spilled over to the people because they still cannot find a job" he said.

Since the data is concentrated on small scale, policy makers should make a paradigm shift addressing on the large scale. Alternative polices to address those who are in the extreme poverty level may be prioritized. What the government should do based on the result is to increase tremendously the social aspect. But the question is which part of the social aspect? According to Ibon foundation, the government should finance its own manufacturing industries making use of the natural resources being currently mined by China; Japan; and the US and other countries. With the 2013 high credit rating which indicated higher economic growth to some could be used as leverage for the government to invest in mining its own natural resources thereby creating jobs - because after all, the current economic growth has not indicated high social status due to scarcity of jobs. This is feasible considering that Philippines has a higher economic aspect but less in the social aspect. Theoretically, in this scenario no one is below the poverty line, hence no one is considered poor. The per capita income if distributed equally, everybody earns above the threshold limit of poverty. Thus, if other aspects of progress are also considered, particularly the social aspect, poverty in the Philippines will be solved. The Philippines' present economic model depended on consumption, strong remittances from its large overseas workforce and the business process outsourcing industry, which employs college graduates. Usui (as cited by PDI, April 2013) is right in asking "Why do we need a strong industrial base?". He added: "to give jobs not only to the highly educated college graduates, but also to high school graduates". 
Mll Macrothink

2003

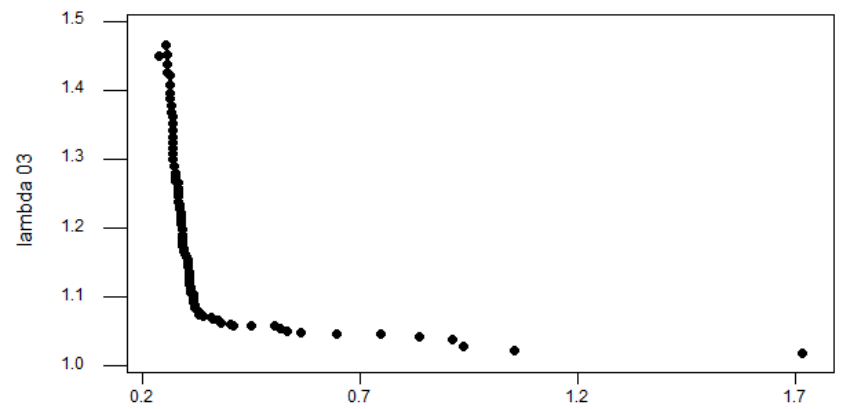

2009

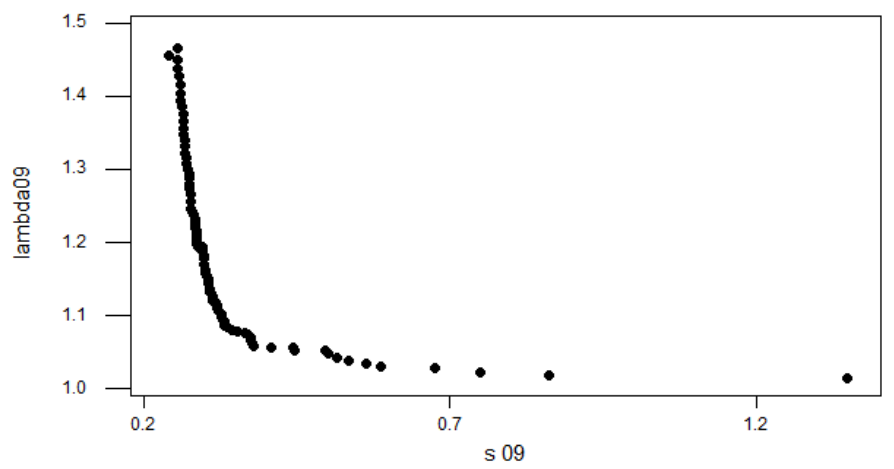

Journal of Public Administration and Governance

ISSN 2161-7104

2016, Vol. 6, No. 2

\section{6}
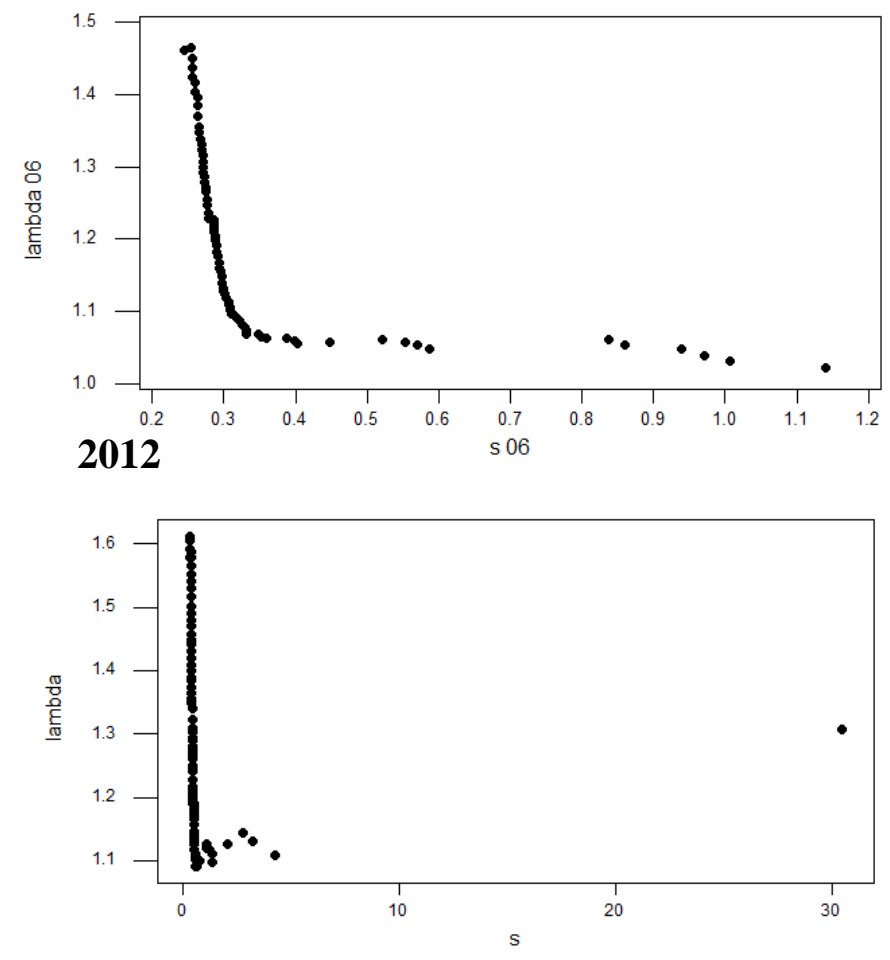

\section{Conclusion}

Taking a long view of the status of poverty - a view from 2003-2012, the fractal movements of the incidence of poverty is due to the government interventions implemented in reducing poverty in the Philippines. It was only in 2010 that the Conditional Cash Transfer (Pantawid Pamilya) was implemented by the government hence resulting to a drastic change of the fractal scale in 2012.

This paper started by emphasizing the need for strategic focus and the imperative of igniting sustained growth among the poor if poverty reduction objectives, such as those reflected in the Millenium Development Goals, are to be achieved. The model of fractal poverty in the Philippines introduced another nature of the problem. The fractal model shows that the poverty incidence is dictated by the province whose incidence is high. This means that if the poverty incidence of the province will be primarily addressed, it will affect the poverty scenario of the Philippines. Policy makers if looking for key indicators why Filipinos have some difficulty escaping poverty may focus on the province with the highest incidence. Compared, to the basic statistics where we simply compare any significant changes of poverty per year, the fractal model opens another pathway to get out of poverty.

\section{References:}

Africa, Sonny (2012, July). Perception Economics: Two Years of the Aquino Administration.

$\begin{array}{llllll}\text { Retrieved from } & \text { Ibon } & \text { Foundation } & \text { July } & 20, & 2012 .\end{array}$ http://www.ibon.org/ibon_features.php?id=242 


\section{I Macrothink}

Journal of Public Administration and Governance ISSN 2161-7104 2016, Vol. 6, No. 2

Barrett, Christopher B. and Brent M. Swallow. "Fractal Poverty Traps". World Development Journal. Vol. 34 Issue 1 January 2006 Page 1-15. Open Access: Elsevier. Retrieved Dec. 5, 2015

Barnett, B. J., Barrett, C. B., \& Skees, J. R. (2008). Poverty traps and index-based risk transfer products. World Development, 36(10), 1766-1785.

Barrientos, A. (2013). Does vulnerability create poverty traps? (pp. 85-111). Palgrave Macmillan UK. Retrieved Dec. 4, 2015.

De Guia, Patnubay (2011, July 4) Aquino's Pantawid Pamilyang Pilipino Program as a Strategy to Alleviate Poverty is not Freedom From Retrieved February 12, 2012 from PRWC Blogs. http://theprwcblogs.blogspot.com/2011/07/aquinos-pantawid-pamilyang-pilipino.html

Easterly, William. Beautiful Fractals and Ugly Inequality. AIDWATCH. New York University

Development Research Institute (DRI). Published Online: September 9, 2010 http://aidwatchers.com/2010/09/beautiful-fractals-and-ugly-inequality/

Ellao, Janes Ann J. (2010 October 23). Critics Slam 'Conditional Cash Transfer Program'as

Unsustainable, Corruption-Prone. Retrieved December 23, 2012 from www.Bulatlat.com.

Health Statistics. Fetal Deaths with Cause. Retrieved May 23, 2012 from the Department of Health, Republic of the Philippines. www.doh.gov.ph

Health Statistics. Infant Mortality. Retrieved May 23, 2012 from the Department of Health, Republic of the Philippines. www.doh.gov.ph

Health Statistics. Leading Causes of Morbidity. Retrieved May 23, 2012 from the Department of Health, Republic of the Philippines. www.doh.gov.ph

Health Statistics. Maternal Deaths. Retrieved May 23, 2012 from the Department of Health, Republic of the Philippines. www.doh.gov.ph

Inside Thailand Review (n.d.). Poverty Eradication. Retrieved January 16, 2012 from the Government Public Relations Office, Foreign Office

http://thailand.prd.go.th/ebook/review/content.php?chapterID=17

Inter-American Development Bank Social Protection in Asia.(2011, March 30). Social Protection in South East Asia: Emerging Issues and Perspectives for Research and Policy. $\begin{array}{lllll}\text { Retrieved } \quad \text { February } & \text { 9, } & \text { from }\end{array}$ http://www.socialprotectionasia.org/pdf/smeru-spa-wp04.pdf.

Morduch, Jonathan (1999, March 25). Reforming Poverty Alleviation Policies. Retrieved from Conference on "Economic Policy Reform: What We Know and What We Need to Know"

held at the Center for Research on Economic Development and Policy Reform, Stanford University, September 16-19, 1998. Retrieval Date: March 10, 2013. http://www.reforming_poverty_alleviation_policies. 
Morrison James L. (n.d.) Policy-Impact Analysis: A Rational Method to Respond to the Challenges Faced. Retrieved by April 4, 2012 from Higher Education in the Eighties. ERIC Education Resources Information Center. http://www.eric.ed.gov/ERICWebPortal/search.

Pantawid Pamilyang Pilipino Program (n.d.) Pantawid Pamilyang Pilipino Program FAQ / Briefer. Retrieved January 14, 2012 from the Department of Social Welfare and Development (n.d.) http://pantawid.dswd.gov.ph/images/stories/briefernew.pdf

Pantawid Pamilyang Pilipino Program (n.d.) 4Ps Concept Paper for MCC as of 21 January 2009, 10:30 AM. Retrieved January 14, 2012 from the Department of Social Welfare and Development (n.d.) http://pantawid.dswd.gov.ph/index.php/pantawid-pamilya-cso-faq

Pantawid Pamilyang Pilipino Program (2009, Dec. 10) 4Ps Beneficiary Now 1 Million. Retrieved January 14, 2012 from the Department of Social Welfare and Development (n.d.)

http://pantawid.dswd.gov.ph/index.php/news/115-4ps-beneficiaries-reaches-to-one-million-h ouseholds-

Phil. Daily Inquirer. Philippine Poverty Incidence Unchanged in Past 6 Years: 10\% of Filipino Families Rated 'extremely poor'. April 24, 2013. http://newsinfo.inquirer.net/396237/ph-poverty-unchanged\#ixzz3dp4nlPvT

Poverty Statistics. Poverty incidence unchanged, as of first semester 2012-NSCB (Posted 23 April 2013) Retrieved May 1, 2013 from the National Statistics Coordination Board, Republic of the Philippines. http://www.nscb.gov.ph/poverty/default.asp

Poverty Statistics. Retrieved May 27, 2012 from the National Statistics Coordination Board,

Republic of the Philippines. http://www.nscb.gov.ph/poverty/default.asp

Proportion of Households with Income Below Poverty Threshold. Retrieved May 23, 2012 from the National Statistics Office, Republic of the Philippines. Www.census.gov.ph

Proportion of Households with Income Below Subsistence Threshold. Retrieved May 23, 2012 from the National Statistics Office, Republic of the Philippines. www.census.gov.ph

Proportion of Households who Experienced Food Shortage. Threshold. Retrieved May 23, 2012 from the National Statistics Office, Republic of the Philippines. www.census.gov.ph

Proportion of Persons who are Unemployed. Retrieved May 23, 2012 from the National Statistics Office, Republic of the Philippines. www.census.gov.ph

Sachs, Jeffrey D. The end of poverty: economic possibilities for our time. Penguin, 2006.

Santiago Levy, Vice President for Sectors and Knowledge (2009). Controversial Issues on the Role of Conditional Cash Transfer Programs to Improve Nutrition. Retrieved January 28, 2012 from International Food Policy Research Institute (IFPRI) (n.d.)

Virola, Romulo. 2009 Official Poverty Statistics. National Statistics Coordination Board. Presented on 


\section{Macrothink}

February 8, 2011 to the Press Conference on the 2009 Official Poverty Statistics. Retrieved May 28. 2012 National Statistics Coordination Board, Republic of the Philippines.http://www.nscb.gov.ph/poverty/2009/Presentation_RAVirola.pdf

\section{Copyright Disclaimer}

Copyright for this article is retained by the author(s), with first publication rights granted to the journal.

This is an open-access article distributed under the terms and conditions of the Creative Commons Attribution license (http://creativecommons.org/licenses/by/3.0/). 